\title{
The Forbidden Passion: Mughultāy's Book on the Martyrdom of Love and its Censorship
}

\section{La pasión prohibida: el libro sobre el martirio por amor de Mugultāy y su censura}

\author{
Monica Balda-Tillier* \\ Ilcea-Cemra, Université Stendhal Grenoble 3, Grenoble
}

\begin{abstract}
Al-Wädih al-mubīn fì dhikr man ustushhida min al-muhibbìn by Mughulțāy (d. 762/1361) is the only love treatise whose reading was ever prohibited in the entire history of the genre. The reasons alleged in ancient sources are insufficient or not explicit enough on the reasons why Mughultāy's book was burned in the public square and withdrawn from the book market in $14^{\text {th }}$-century Cairo. This article consists of an attempt to understand the reasons behind this prohibition.
\end{abstract}

Key words: Passionate love; Theory of profane love; Love treatises; Islam; Book censorship; Mamluk period; Hadìth al- 'ishq.
La obra al-Wādih al-mubìn fi dikr man ustušhida min al-muhibbīn de Mughultāy (m. $762 / 1361$ ) es el único tratado sobre el amor cuya lectura fue prohibida en toda la historia del género. Las razones que se aducen en las fuentes antiguas son insuficientes o no lo bastante explícitas sobre los motivos por los que el libro de Mughultāy fue quemado en la plaza pública y retirado del mercado en El Cairo del siglo VIII/XIV. Este artículo es un intento por entender los motivos que condujeron a la prohibición.

Palabras clave: amor apasionado; teoría del amor profano; tratados sobre el amor; islam; censura de libros; periodo mameluco; hadịt al'iš $q$.

Al-Wädih al-mubin fi dhikr man ustushhida min al-muhibbin is a love treatise written by Mughultāy b. Qilìj b. 'Abd Allāh al-Bakjarī, a Mamluk writer who lived in fourteenth-century Cairo (d. 762/1361). ${ }^{1}$

${ }^{*}$ This paper was presented on the panel Knowledge under control. Political and religious censorship in Islamic societies, WOCMES, Barcelona, 19-24 July 2010, organized by the ARG-ERC project KOHEPOCU ("Knowledge, heresy and political culture in the Medieval Islamic West"). I'm very grateful to Adam Talib (American University of Cairo) for revising and editing the English of this article.

${ }^{1}$ For the biography of Mughultāy and the withdrawal of al-Wädih from the book market see al-Suyūțī, Dhayl Tabaqāt al-Huffāz li-l-Dhahabī, pp. 133-141; Ibn Hajar al'Asqalānī, al-Durar al-kāmina fì a yān al-mi'a al-thāmina, v. 4, p. 352; Ibn Taghrī Birdī, al-Nujūm al-zāhira fì mulūk Miṣr wa-l-Qāhira, v. 11, p. 762; Ibn Quṭlūbughā, Tāj al-tarājim 
The author was an expert on hadith as well as being a teacher and taught in almost all the biggest madāris of Cairo. Al-Wädih is the only book of $a d a b$ he ever wrote.

Mughultāy's book opens with an introduction explaining the author's theory of love, followed by a biographical dictionary of those who died for love and who are considered by Mughulțāy to be martyrs. This work has been censored twice but - in both instances - the reasons given for its interdictions are insufficient or not explicit enough to explain it. It was first censored in Egypt in the $14^{\text {th }}$ century - Mughultāy was put in prison, and the book was burned in the public square then withdrawn from Cairo's book market. ${ }^{2}$ Religious authorities of the time argued that the book contained a hadith which disrespected ' $\overline{\mathrm{A}}$ 'isha, the Prophet's favourite wife, and that its introduction contained some licentious verses and should therefore not be read. ${ }^{3}$

Referring to the licentious verses, we note that this was also the reason given for banishing Mughultāy's book in contemporary Syria. ${ }^{4}$ However, in Mughultāy's book there are only a few verses in the introduction which could be considered licentious; the remaining text only deals with stories of chaste ' $u d h r i \bar{l}$ love. I do not believe that a few dissolute verses could have caused such a hostile reaction in the $8^{\text {th }} / 14^{\text {th }}$ century. Therefore this second alleged reason will not be dealt with.

As for the first reason that has been given, ' $\overline{\mathrm{A}}$ 'isha is mentioned three times in ahädith in al-Wädih and in two of the cases the ahädith do not appear to question the integrity of the Prophet's wife. ' ' $\overline{\bar{A}}$ 'isha

fi tabaqāt al-hanafìya, p. 77; al-Ṣafadī, A'yān al- 'aṣr wa-a'wān al-nașr, v. 3, p. 276. A well documented study and an exhaustive comparison of sources about Mughultāy's life can also be found in Miskinzoda's doctoral thesis On the margins of sìra: Mughultà '̄ (689762/1290-1361) and his place in the development of sira literature, pp. 54-62.

2 Mughultāy was first attacked for his book on 'ish $q$ by Khalìl b. Kaykaldī al- 'Alā' '̄ (d. 760 or 761/1358 or 1359). He refused to recognise any guilt and was therefore taken to the Hanbalite judge al-Muwaffaq, who condemned him and sent him to prison. Later, Emir al-Jankalī b. al-Bābā (d. 746/1345) ordered his release. Ibn Hajar al-'Asqalānī, alDurar, v. 4, p. 352.

${ }^{3}$ See Mughultāy's biographies we quoted in note 1 for the hadìth and al-Wädih, pp. 74-79 for the licentious verse.

${ }^{4}$ When, in 1997, a complete edition of the book was published in Lebanon, Syrian authorities banned its sale. The book was censored for being pornographic.

5 The first of these ahädith tells us that the very first instance of love in Islamic history is the Prophet's passion for his wife 'A 'isha. Even though he was fasting, Muhammad could not restrain himself from kissing her (al-Wädih, p. 28). The second hadith mentions 
is to be found for the third time in the isnäd of the hadith al- 'ishq (man 'ashiqa fa- 'affa fa-māta māta shahìdan). ${ }^{6}$ The interdiction of al-Wādih is related with this later prophetic apocryphal hadith, even if simply quoting this saying cannot be the only reason for such a strong reaction, as almost all the authors of love treatises quoted the hadith al- ishq. ${ }^{7}$ Therefore, the real cause of Mughultay's book being banished should not be sought in the quotation as transmitted by ' $\overline{\mathrm{A}}$ 'isha, but in Mughulțāy's theory of love which is based on this hadith.

In order to discover why al-Wädih was censored, I compared different aspects of Mughultāy's book with other books on love that have not been censored. Al-Wädih is indeed the only treatise of love to have ever been prohibited in the entire history of the genre ( $8^{\text {th }}$ to $17^{\text {th }}$ centuries). Therefore it soon became clear to me that Mughultāy's approach to profane love's theory must have been, to a certain extent, different from the others if Mamluk religious authorities of the time decided that it should not be read.

In order to explain the reasons for its censorship, I will first describe the structure and content of al-Wädih and its status within the history of classical Arabic literature. I will then expound on Mughultāy's theory of love and demonstrate how he modified and adapted stories from the literary tradition on love to accommodate his literary and ideological purposes.

an incident in the Prophet's life when the camel carrying ' $\bar{A}$ 'isha ran away during a raid, and Muhammad remained transfixed with grief, unable to move and crying in pain: "My wife, my wife" (al-Wädih, p. 28).

6 The hadìth al- 'ishq (man 'ashiqa fa- 'affa fa-màta mäta shahìdan) has two different $i s n \bar{a} d \mathrm{~s}$. In the one that is most frequently quoted, the last transmitter of the hadith before Muhammad is Ibn 'Abbās (who died after 68/686-7). However, a few authors, including Mughultāy (p. 19), mention the second isnād where ' $\overline{\mathrm{A}}$ 'isha is the last transmitter not Ibn 'Abbās (al-Khațīb Baghdādī, Ta'rìkh Baghdād, vol. 12, p. 429); al-Suyūṭī also mentions a version of the hadith al- 'ish $q$ where the last transmitter is ' $\overline{\mathrm{A}}$ 'isha and which he attributes to al-Khațìb. Al-Suyūtịi, al-Durar al-muntatira fì l-ahädìth al-mushtahira, p. 383. See also Balda-Tillier, Un traité d'amour tardif : les précis des martyrs de l'amour de Mugulțāy, pp. 154-156.

7 On the hadith al- 'ish $q$ discussion in love treatises see Gruendler, "Pardon Those Who Love Passionately," pp. 191-192. 


\section{A. The Structure of al-Wädih and its Position within the Genre}

In Medieval Arabic literature, passionate love was a common theme in poetry since the pre-Islamic period. It first appears in prose at the beginning of the $2^{\text {nd }} / 8^{\text {th }}$ century. A considerable number of authors wrote books on this subject, such as the Kitāb al-Zahra by Ibn Dāwūd (d. 297/910), Tawq al-hamāma by Ibn Hazm (d. 456/1064) and Dhamm al-hawā by Ibn al-Jawzī (d. 597/1200). These books have some characteristics and themes in common -as the description of the essence of passionate love (māhiyyat al- 'ishq), including its forms, causes and effects on those in love and they can therefore all be considered to be part of the literary genre of love treatises. ${ }^{8}$

\section{A.1. The Alphabetical Order}

Mughultāy's book comprises an introduction ${ }^{9}$ followed by one hundred and sixty-four akhbār about people who loved passionately, remained chaste and died because of their love. The book contains all the characteristics that typify the genre according to Lois Anita Giffen and therefore belongs to it.

However, the organisation of the material in Mughultāy's book sets it apart from all other love treatises. In the other books about love, the material is organised by theme with each chapter headed by title, which automatically categorises the ensuing $a k h b \bar{a} r$. The author's argument is immediately illustrated by several stories or poems. Mughultāy chose to organise his material in alphabetical order, not by theme.

Putting the text into alphabetical order carries several implications. It allows Mughultāy to place all his stories on an equal footing without ascribing hierarchical order to their content. In Mughultāy's work, a story about a man's love for Allāh, where he dies after hearing a verse from the Koran, could be followed immediately by a story about a man who takes his own life after losing his beloved. Mughultāy con-

${ }^{8}$ I agree on this point with Lois Anita Giffen: Giffen, Profane Love among the Arabs, the Development of the genre. On the literary history of the genre see: Balda-Tillier, "Genèse et essor d'un genre littéraire: les traités d'amour dans la littérature arabo-islamique médiévale (II /VIII - VIII $/ \mathrm{XIV}^{\mathrm{e}}$ siècle)," pp. 121-130.

${ }^{9}$ Mughulțāy, al-Wädih, pp. 17-107. 
siders both lovers as examples that should be followed by devout Muslim.

The use of alphabetical order is also part of Mughulțāy's argumentative strategy. In classical Arabic literature the use of alphabetical structure is characteristic of tabaqāt - collections of biographies of pious men. From Mughultāy's point of view his lovers are comparable to these pious individuals and, as such, worthy of being followed by every good Muslim. To read and learn from al-Wädih is then akin to walk on a path that leads to holiness.

\section{A.2. The hadìth about 'Ishq}

The use of alphabetical order is not the only original feature in the structure of al-Wädih. However, one feature that sets al-Wädih apart is that the entire book is based upon what is traditionally called hadith al-ishq. This prophetic hadith states that he who loves passionately, remains chaste and dies for this love should be considered a martyr. This is a late hadith and has been introduced for the first time in a love treatise by Ibn Dāwūd (d. 297/910) in his Kitāb al-Zahra. It is probably apocryphal, but Mughulțāy argues that its isnād is 'true' (sahịh). ${ }^{10} \mathrm{He}$ believes that almost all lovers whose stories are told in al-Wädih should be considered martyrs. A great number of Mughultāy's akhbār begin with the words "martyr/s or female martyr" (shahid/a or shahìd $\bar{a}$ /shuhadā'). This word defines the status of the lover who is the main character in the akhbār that follows. Only a few akhbār are preceded by qatìl/qatīla, "killed (by love)," indicating that Mughultạy does not consider the lover a martyr.

The idea of being martyred for love was not accepted by everyone. Hanbalite authors in particular thought that profane love could never lead to Paradise as passion for another creature takes man away from loving God. ${ }^{11}$ Making 'A' 'isha, who is such an important and revered

${ }^{10}$ Mughulțāy, al-Wā dih, p. 19.

11 Stefan Leder notes for instance that the Hanbalite Ibn al-Jawzi, author of Dhamm al-hawā, "quotes different transmissions of the hadìth al- 'ishq. This hadìth is shown to be an obvious forgery [...]. Dying of tragic love is attributed to certain aspect of character in some desert Arabs (Uḍrite) and in no way receives any philosophical qualification". Leder, Ibn al-Ǧauzi und seine Kompilation wider die Leidenschaft, p. 328. 
figure in Islam, the most important transmitter of this controversial hadith, as we mentioned Mughultạy did, may have been one of the reasons why al-Wädih was censured, but it is certainly not the only one.

A.3. The Debate about the Value of 'Ishq within the Literary Genre of Love Treatises

The Risālat al-'ishq and the Risālat al-qiyān by al-Jāhiz (d. 255/869) are considered the earliest treatises on love to have survived. ${ }^{12}$ By the time Mughultạy came to write his treatise in the $8^{\text {th }} / 14^{\text {th }}$ century the genre was already well established. All these works focus on the definition of 'ishq. A large number of authors stress the difficulty of giving a precise definition for the term 'ishq. 'Ishq is a non-Koranic word meaning 'passionate love'. But the meaning of this word has been debated throughout the history of the genre. As Muhammad Arkoun says in the Encyclopaedia of Islam, "In its most general acceptation, ish $q$ describes the irresistible desire to obtain possession of a loved object or being. It betrays therefore in one who experiences it (the 'ashiq) a deficiency, a want that he must supply at any cost in order to reach perfection $(\mathrm{kam} \bar{a} l)^{13}$ ".

The initial debate concerned providing a distinction between $h u b b$ and 'ishq. Al-Jāhiz explained that hubb can be used for all kinds of love: the love of a mother for her children, the love of a son for his parents, the love between siblings, and the love between couples. ${ }^{14}$ In contrast, he stated that ishq could only be used to describe passion between two people in love and it has a connotation of excess that we do not find in $h u b b$.

Al-Jāḥiz stated:

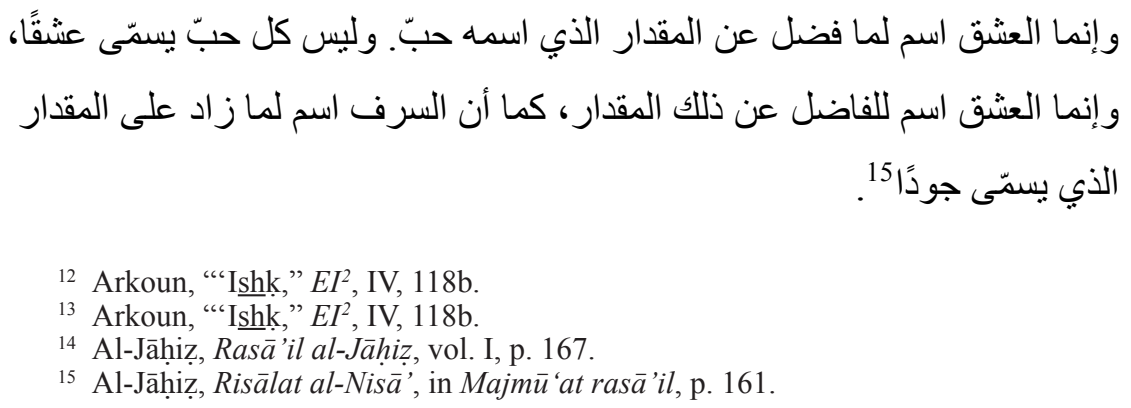


'Ishq is what transgresses $h u b b$. All love cannot be called 'ishq, but 'ish $q$ exceeds the limits of $h u b b$ - just as prodigality exceeds the limits of generosity. ${ }^{16}$

The excessive quality of 'ish generates an uncomfortable feeling from a moral point of view, and this has produced some considerable discussion among authors writing love treatises.

'Ishq is a powerful, contravening and excessive feeling which oversteps the limit of what is reasonable. It causes malady and madness and - in many cases - is responsible for the death of the lover. As a consequence of this, "ishq is considered to be a negative emotion by some authors. The "sunna" of "ish completely turns the idea of duty, of good, of licit and illicit upside down. An excessive love is contrary to all moral, social and religious values, which are based on the idea of moderate behaviour. ${ }^{17}$ 'Ish $q$ belongs outside of marriage. It competes with religious values because it has its own rites and holy places. ${ }^{18}$ Majnūn Laylā, one of the most famous lovers in Arabic literature, declares that he prays in the direction of Laylā's encampment. In many love stories, the lovers recite verses to their beloved while circumambulating the Kaaba. Ibn Qayyim al-Jawziyya (d. 751/1350) compares 'ish $q$ to idol worship, the most serious sin in Islam. 'Ishq causes devotion and adoration, which are attitudes that the believer must reserve for God alone. ${ }^{19}$

Not all authors who wrote love treatises agree in condemning 'ishq. On the contrary, some of them, like Ibn Dāwūd and Mughultāy, considered it the highest and most noble virtue a man could have. Only a few select people are able to feel ishq. This concept of 'ishq is tied to the hadith al- ish $q$ mentioned above. In Islam martyrdom is considered the most commendable way to die and the best way to serve God. ${ }^{20}$ To feel

16 All the translations provided are my own.

17 Ben Slama, al-'Ishq wa-l-kitāba, p. 269.

18 The similarity between the values and rites within religion and profane love has also been noticed in Occidental courtly love. In his book Love and Death in Medieval French and Occitan Courtly Literature, Martyrs to Love (p. 10), Simon Gaunt says: "Courtly love literature appropriates and incorporates models of sacrifice and desire associated with religious discourse and practices to produce an alternative ethical space in which salvation and redemption may be sought through the passionate attachment to another human being, rather than to God".

19 Bell, Love Theory in Later Hanbalite Islam, p. 139.

20 In his article on the martyrdom of passionate lovers, M. Jarrar observes that "The human being has aimed since time immemorial, at fulfilling passionate love through reunion with the 'sacred' to give his desires an eternal realisation which transcends death so that 
passionate love ( $i s h q$ ) and to die for it is a way to enter Paradise. Suffering and not succumbing to one's own desires in order to remain chaste despite the strength of the passion is a quality that can be likened to jihād on the battle field. From this point of view, passionate love which causes madness and death is imbued with positive values, virtues and merits.

The debate focused particularly on the responsibility of lovers who died due to 'ishq. Some authors like Mughultāy defend passionate love on the assumption that no one can freely choose to feel ishq. ${ }^{21}$ 'Ishq develops only in souls that are predestined to it from birth. For others, like the Hanbalite Ibn Qayyim al-Jawziyya, 'ish $q$ is the movement (haraka) or the foolishness (jahl) of an empty heart (qalb fârigh) and it must be condemned. ${ }^{22}$ It is passion that enslaves men and against which men must fight with intellect. According to Abū Bakr al-Rāzī (d. 313/925 or 323/935), only those who are insensitive and endowed with the coarsest temperaments choose to feel ish ${ }^{23}$

\section{B. Mughultāy's Theory of 'Ishq}

As others before him, Mughultāy stresses the difficulty of giving a precise definition of 'ishq. Many authors spoke about the nature of ishq, but real definitions are rare. Most of them just describe what causes 'ishq. In his analysis of 'ishq, Mughultāay concentrates on the question of whether it is man's responsibility to fall in love and suffer 'ishq or if it is God's will.

\section{B. 1. Mughultāy's Argument about 'Ishq}

Mughultāy's argument starts with the quotation of a verse from the Koran which is a prayer to God asking him not to inflict on man any evil that he cannot bear. ${ }^{24}$ Then he stresses the idea that man is a weak

the positive energy could negate death. Holy war is one way to offer pain as a sacrifice to the "sacred' in return for the perpetuation of Eros which constitutes the essence of 'being": Jarrar, "The martyrdom of passionate lovers, Holy war and sacred wedding," p. 98.

${ }^{21}$ Al-'Aẓm, Fì l-hubb wa-l-hubb al-'udhrì, p. 18.

${ }^{22}$ Ibn Qayyim al-Jawziyya, Rawdat al-muhibbin, p. 91.

23 Abū Bakr al-Rāzì, al-Rasā'il al-falsafiyya, pp. 39-40.

${ }^{24}$ Surah 2, The Cow, 286. 
creature. This weakness manifests itself particularly when a man sees a very beautiful woman. Another hadith mentions that there is nothing like women to cause men to quarrel. ${ }^{25}$ This passage shows that to resist 'ish $q$ and all its temptations has always been difficult even for the Prophet Muhammad. The lovers of his stories bear no responsibility for their passionate love or for being reduced to madness and death by it. In order to support this belief, Mughultay quotes also a medical theory according to which 'ish $q$ is considered an illness that befalls people without compassion. ${ }^{26}$ The lover who is affected by this mortal illness can never be considered responsible for it. That is why people should feel sympathy for the passionate lover and help him.

All these arguments provided by al-Wädih show that man suffers from 'ishq independently of his will. Lovers can never be considered responsible for the passion they feel. Passion does not harm their souls even when it kills the lovers themselves. On the contrary, it is a kind of grace that God bestows only on the noblest of souls, on those who have been predestined to receive it from birth. To suffer a passion that ends in death is a means by which the martyr is rewarded with a holy status. ${ }^{27}$

\section{B. 2. Theory of Mushākala}

According to another theory, lovers are connected by mushākala (resemblance, affinity), and 'ishq is brought about by the 'elective affinity' of two souls. Ibn Dāwūd describes the way this affinity affects the souls: ${ }^{28}$

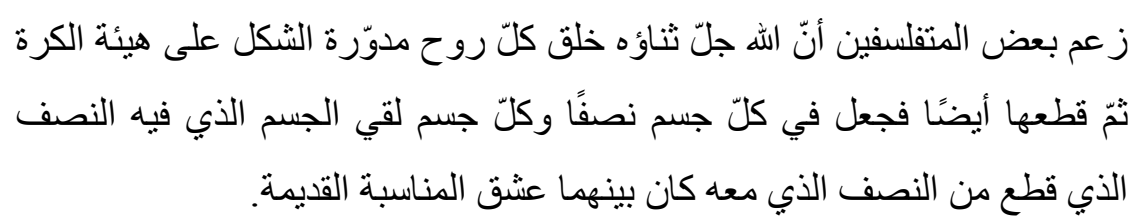

${ }_{25}$ Mughulțāy, al-Wā dih, p. 23.

${ }^{26}$ Mughultāy, al-Wädih, p. 66. On the malady of love see also Ben Slama, al- 'Ishq wa-l-kitāba, p. 135 and Biesterfeldt and Gutas, "The malady of Love," pp. 21-55.

${ }^{27}$ Martyrdom is never considered a failure, but as a virtual and moral victory. See Pannewick, "The martyred Poet on the Cross in Arabic poetry," p. 105.

${ }^{28}$ Ibn Dāwūd al-Iṣfahānī, Kitāb al-Zahra, p. 15. 
A philosopher argued that God (praise Him) created all souls round like a ball and then divided them in two, putting one half into each body. Whenever a body meets the other body which contains the other half of its soul there will be love between the two of them because of the ancient affinity between them.

Mughultạy quotes also this passage on the theory of mushākala (affinity): ${ }^{29}$

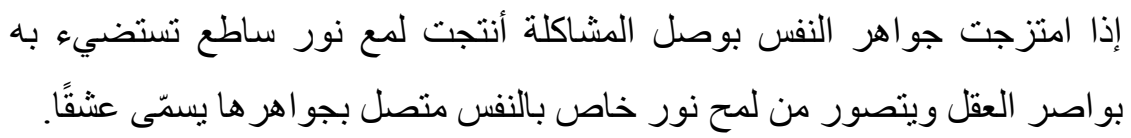

If the essence of one soul mixes with another by means of their intellectual empathy it triggers a twinkling sparkle of light which illuminates the eyes of the mind. This light generates yet another light which is specific to the soul. This second light is connected with the essence of the soul and is called 'ishq.

This theory is dependent on Fate, because the affinity between the two souls is decided upon before the bearer of the soul is born and is therefore perfect for authors like Mughultāy who support the theory that one is obliged to fall in love (that is, the bearer has no choice) ${ }^{30}$

This affinity can only occur between two very elevated and noble souls and can never occur between two lower or common souls. When it occurs in the human heart, 'ish $q$ renders the bearer more noble. Mughultāy says that this theory follows the thinking of ancient philosophers like Plato, Socrates, Aristotle, Archimedes, etc. ${ }^{31}$ The pre-destined affinity between the two souls guarantees that the love will persist because without this affinity passion would peter out very quickly, and the lover would soon grow bored of his beloved..$^{32}$ Mughultāy stresses this theory and quotes from early classical scholars because their ideals correspond perfectly to the idea of passionate love, which he maintains and defends. This love emanates from the brain and the lover must remain chaste because a sexual relationship would destroy 'ishq. Furthermore, 'ish $q$ has no time limit - 'ish $q$ exists before the souls enter the body and it does not end with the lover's death as it is attached to soul, not to the mortal body. This theory also allows Mughultây to in-

29 Mughultāy, al-Wādih, p. 46-47.

${ }^{30} \mathrm{Jid}$ 'ān, "Dà' ‘̀ al-mushākala fi nazariyyat al-hubb 'inda al-'Arab," p. 88 and p. 103.

${ }^{31}$ Mughultāy, al-Wädih, p. 48.

32 Mughultạy, al-Wädihị, p. 51. 
troduce an eschatological dimension to his concept of 'ish $q$ in which love and death are closely connected, because through one's martyrdom of love in this world happiness in the next world is attained.

\section{B. 3. Love as "Ignorance" or "humiliation"}

Mughultāy also quotes what he says being Aristotle's definition of ishq: $:^{33}$

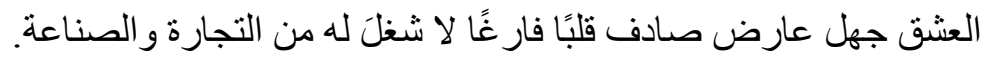

'Ish $q$ is a form of ignorance that randomly affects an empty heart, a heart that is not preoccupied with commercial affairs or work.

We find this same definition of 'ish in many books within the classical Arabic tradition, but Mughultạy's version has two very relevant differences. ${ }^{34}$ Firstly, other versions omit the present participle 'ârid (randomly), which stresses the haphazard nature of ishq. Secondly, other versions claim that 'ish $q$ affects empty hearts without referring to these hearts being empty because they are detached from any lucrative activity. Omitting this part of the definition gives a negative value to the definition of 'ish $q$ by simply attributing it to an idle heart. In contrast, specifying the nature of these preoccupations as commercial affairs or manual labour changes the meaning of the definition and renders 'ish $q$ into a positive value that preoccupies the mind with concerns other than that of making money.

Mughultāy also quotes negative definitions of love. According to al-Wädih, the author of al-Manthür wa-l-manzūm, ${ }^{35}$ whose name is not mentioned, stated that in the past some people believed that 'ishq, haw $\bar{a}$ (another term for love which can have more sensual connotation at times) and mahabba (the love of a mystic for God) have exactly the

${ }^{33}$ Mughultāy, al-Wādih, p. 45.

34 The definition in $a \dot{l}-\mathbf{W} \bar{a}$ dih can be found only in three relatively late books: al-Tawhīīi (d. 414/1023), in al-Bașà'ir wa-l-dhakhā'ir, vol. 4, p. 79; al-Zamakhsharī (d. 538/1144) in Rabì 'al-abrār, vol. 3, p. 122 et Dāwūd al-Anțākī (d. 966/1559), in Tazyìn al-aswāq, vol. 1, p. 47.

${ }^{35}$ The author of al-Manthūr wa-l-manzūm is Ibn Abī Țāhir Ṭayfür (d. 280/893) who wrote about fifty literary works and was also a poet: Rosenthal, "Ibn Abī Ṭāhir al-Ṭayfür," $E I^{2}$, III, 692b. 
same meaning. They realized later that ishq was a sort of mad love (istihyām) or humiliation (tadarru) while hawa was man's desire for something he may wish for through positive or negative acts. Mahabba can mean all of these things. ${ }^{36}$

In the above definition ' $i s h q$ is considered to have negative properties as it makes the lover sad and miserable by humiliating him and bringing on his madness. Despite this, Mughultāy shows that this extreme form of love which can never end in happiness is a positive value for those who experience it as 'ish $q$ is too noble to be experienced by those with a trivial destiny. 'Ishq transcends the human condition through the suffering it inflicts, raising the lover to the status of a hero or a saint. ${ }^{37}$ A person who can resist this kind of love, which is described as a plague, and stay chaste must be regarded as 'perfect'. To be plagued is a necessary condition to attain perfection. For Mughultāy 'ish $q$ is a more noble sentiment capable of enlightening the elite refined man who suffers from it. ${ }^{38}$

\section{B. 4. Mughultāy's Idea of 'Ishq}

From Mughultāy's theory of 'ishq, we can summarize the following:

1) 'Ish $q$ is imposed upon the soul at birth or before it. ${ }^{39}$

2) It is a fateful condition that can only touch souls with similar virtues, never to exist between two souls with similar weaknesses. ${ }^{40}$

3) When it takes possession of a soul, ish $q$ will never release it from the subsequent madness, illness and death.

4) Even though it causes a lot of suffering to humans, 'ish $q$ is only apparently harmful, because this suffering will ultimately allow the bearer to enter Paradise through the martyrdom of love.

${ }^{36}$ Mughulțāy, al-Wādih, p. 46.

${ }^{37}$ Sicard, "L'amour dans la Risālat al-Qiyān - essai sur les esclaves chanteuses - de Jāḥiz (m. 255/868)," p. 331.

${ }^{38}$ Renate Jacobi observes that "faithful love, perseverance in the face of despair, is valued and receives religious sanction. Both lover and beloved are morally justified and their torments are to be compensated by God": Jacobi, "The "Udhra: Love and Death in the Umayyad Period," p. 145.

${ }^{39}$ Mughultāy, al-Wädih, p. 58.

${ }^{40}$ Mughultạy, al-Wädihị, p. 56. 
Mughultāay's position with regard to 'ish $q$ could not be clearer: he bases his book on the martyrdom of love and makes his lovers 'holy martyrs', defending this martyrdom against any criticism. To accomplish this, Mughultāy sets out to write a summa of everything that is known about love as a definitive study of 'ishq. Mughultạy not only wished to collect all that is worth saying about ' $u d h r i$ love in a single book, but he also wished to present the one and only 'correct' point of view on the subject.

In his introduction, Mughultāy does not only defend his idea of 'ishq, but he also builds a strong argument in support of the martyrdom of love. He insists that only the most noble souls can feel 'ishq. They are chosen by God for their exceptional qualities, and they suffer more to remain chaste. Because they resist their desires and control their instincts they deserve to become martyrs. This 'holy war' that they struggle with absolves them from all the evil they have done in life. For Mughultāy feeling 'ishq is a noble experience, which educates the refined man or woman who endures it. In this way, the passionate lover becomes a model of righteousness and perfect behaviour that every good Muslim should follow, and the compassionate lover can even be compared to the Prophet Muhammad who has always been considered the supreme example of model behaviour.

\section{The manipulation of the old tradition}

In order to defend 'ish $q$ and render it a 'holy' emotion and practice, Mughultạy presents several theoretical arguments, and also alters the earlier stories about passionate lovers to suit his argument and to provide some 'practical examples'. In his treatise he introduces characters that had never before been considered as martyrs of love. I am going now to examine three $a k h b \bar{a} r$ that show how he took them and transformed them into something new.

\section{1. Waḍ̂̄ al-Yaman}

Waḍạ̄h al-Yaman was known for his exceptional beauty. ${ }^{41}$ Waḍdāh al-Yaman and Umm al-Banin fell in love when they were children. When

${ }^{41}$ Mughulțāy, al-Wādih, pp. 131-135. 
Umm al-Banīn married al-Walīd b. 'Abd al-Malik, Waḍḍ̄ḥ went mad with grief and started wasting away. After having suffered for a long time, he went to al-Shām and started walking around and around alWalid's palace even though there was no possibility of him ever entering it. Eventually, he met one of Umm al-Banin's servants and was able to let his beloved know that he was there. She let him into the palace by hiding him in a chest. One day a eunuch entered Umm al-Banin's room without asking permission and saw Waḍdāh with her. He went straight to al-Walid and told him what he had seen and described the chest where Waḍḍăh was hiding. Al-Walīd then went to Umm al-Banīn and asked her to give him the chest, which he then buried with Waḍḍạ still inside.

After having told this story about Wadḍah and Umm al-Banīn, Mughultāy points out that other stories have been transmitted about these two lovers but he expresses his doubts about these other $a k h b \bar{a} r$ being genuine. First, he says that in al-Ișfahānī's book ${ }^{42}$ it is mentioned that Waḍāh was in love with a girl named Rawdia, and that he wrote a lot of verses about her. ${ }^{43}$ According to Mughultāy this story cannot be true because Waḍḍăh and Umm Banīn had been in love since their childhood and, for Mughulțāy, Waḍ̣āḥ’s love for Umm Banīn was exclusive, and consequently he could not possibly have loved another woman.

According to al-Ișfahānī's version of the story, Waḍ̂ạh and Umm alBanin had not known each other from their childhood. The 'real' story tells that Umm al-Banin asked al-Walid's permission to go on the pilgrimage to Mecca, which he granted. Al-Walid was caliph by this time and he forbade any poet from mentioning her or anyone else who had been with her in their poems. Despite this interdiction, al-Ișfahānī says that Umm alBanin allowed herself to be seen in public and in the presence of love poets; and on one occasion her eyes fell upon Waḍāha and she fell in love with him. She asked him and al-Kuthayyir to compose verses for her. Waḍ̣āḥ mentioned her in his poems by name and when al-Walìd found out about this, he decided to kill him. According to other versions, Waḍdạh composed a lot of poems praising al-Walid. Then somebody told the caliph that he was in love with Umm al-Banin and al-Walid ordered that he be killed.

Mughultāy notices that all these versions indicate that Waḍḍāh and Umm al-Banin had not known each other when they were children and

${ }^{42}$ Abū 1-Faraj al-Ișfahānī, Kitāa al-Aghānī, vol. VI, pp. 33-36.

${ }^{43}$ On the character of Waḍdāh and his passion for Rawḍa see Souissi, "Waḍḍāh alYaman le personnage et sa légende," pp. 268, 268 and 282. 
that she had fallen in love with him later in life. His love for her is not mentioned. Mughultāy thinks that these versions of the story cannot be believed, because somebody who wrote so many verses on Umm alBanin must have loved her since his childhood.

Mughultāy finds another contradiction that makes these versions of the story 'unreliable'. The story of Waḍ̣āh's death took place many years after Umm al-Banin had married al-Walìd, because, at the time of Wad ḍaḥ's death, their son 'Abd al-'Azīz was a fully grown man. This means that Wadḍāh had been bearing his love for her without revealing it for twenty years and this indicates that Waḍdāḥ's love for Umm al-Banīn was a pure, true love that was born during their childhood. By these $a k h b \bar{a} r$, Mughultāay gives us the image of a typical 'udhrì love between Umm al-Banin and Waḍ̣̂̄h. Their love began in their childhood when they were living in the same camp in the desert. It was the one and only true love of Waddāh's life and which eventually brought about his death.

However, the image of this poet given by the literary tradition is not the same as Mughultāy's. According to the Encyclopaedia of Islam, in Waḍḍāh's poems, "the poet appears as a fatā vowed to pursue love and pleasure, and the attainment of the beloved appears as an inevitable consequence of the poet's persistence". ${ }^{44}$ This image of Waḍạhạ did not suit the impression Mughultāy wished to create because it did not fit into his particular theory. That was why he criticised the $a k h b \bar{a} r$ that give an untrue image of Waḍ̣āạ, and Mughultāy only accepts the tradition that makes him fit the role of a lover of the 'udhri model. Moreover, Mughultāy's 'corrections' to the story illustrate his determination to get as close as possible to 'historical truth' and then to make his $a k h b \bar{a} r$ as similar as possible to religious texts.

\section{2. Yazìd b. 'Abd al-Malik}

Let us now take the example of the caliph Yazìd b. 'Abd al-Malik (Yazid the Second), a controversial figure in the historical and literary traditions. The Encyclopaedia of Islam says that medieval sources portray Yazid II (who reigned between 720 and 724) as a frivolous man, a slave to his passions, especially to his singing slaves Habāba and Sallāma. Even though the picture of his frivolous behaviour and Hiabāba's

${ }^{44}$ Arazī "Waḍ̣̣āḥ al-Yaman," EI², XI, 13. 
influence on him have been much exaggerated, he has never been a much-loved figure in Arabic tradition..$^{45}$

For example, Yazīd's passion for Habāba has always been regarded as negative and reproachable. Mughultāyy's portrayal of Yazid ${ }^{46}$ shows him spending hours and days alone with his slave-girl without taking any care of State matters. When she died, Mughultāay tells us, he grieved so much that he refused to bury her for three days, until her body started to smell. Members of his family began to scold him so he let them wash her and bury her. Three days later, however, he wanted to see her again and he ordered her tomb to be opened. She had started to decompose, and had obviously changed a great deal, but he said that he had never seen her look more beautiful. His brother, Maslama, warned him that if he persisted ranting in this way, the people of alShām would say that he had gone mad and they would take away his authority to rule. Yazìd followed his advice and had her buried again. He died of grief a few weeks after Hababa's death.

Mughultāy did not alter the earlier tradition about this caliph. He quoted $a k h b \bar{a} r$ that were used as examples of culpable behaviour and even tells us that he was criticised for this, but, at the same time, he persuades the reader to change his views on this caliph by presenting Yazìd as a martyr. From his point of view, Yazìd's passion for Habāba, which eventually brought about his own death after much suffering and madness, redeems him from all the evil he had previously committed. In Mughultāy's book Yazīd becomes a model of behaviour to be followed by his readers. It is clear that, in Mughulțāy's eyes, love is more important than anything, even more important than state politics.

\section{3. The Young Muslim Man and the Christian Monks}

As a final example I will show how Mughultāy manipulated the contents of a story from an earlier tradition. Mughultāy states that he took his khabar from al-Shayzarî's (who lived in the $6^{\text {th }} / 12^{\text {th }}$ century) Rawdat al-qulūb, but I have compared both versions and found that the stories differ considerably.$^{47}$ I have separated the different versions of the story in two columns and provided translations in the notes.

${ }^{45}$ Lammens, "Yazìd II, b. “Abd al-Malik," $E I^{2}$, XI, p. 311.

46 Mughulțāy, al-Wādih, pp. 388-396.

47 Al-Shayzarī, Rawḍat al-qulūb wa-nuzhat al-muhibb wa-l-maḥbūb, pp. 128-133. 


\begin{tabular}{|c|c|}
\hline Al-Wādih & Rawdat al-qulūb \\
\hline 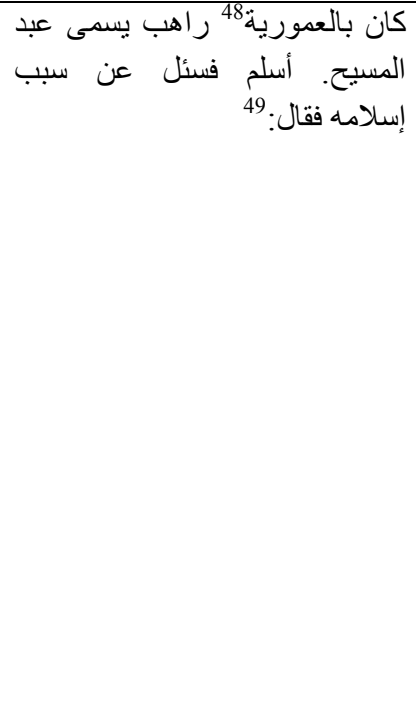 & 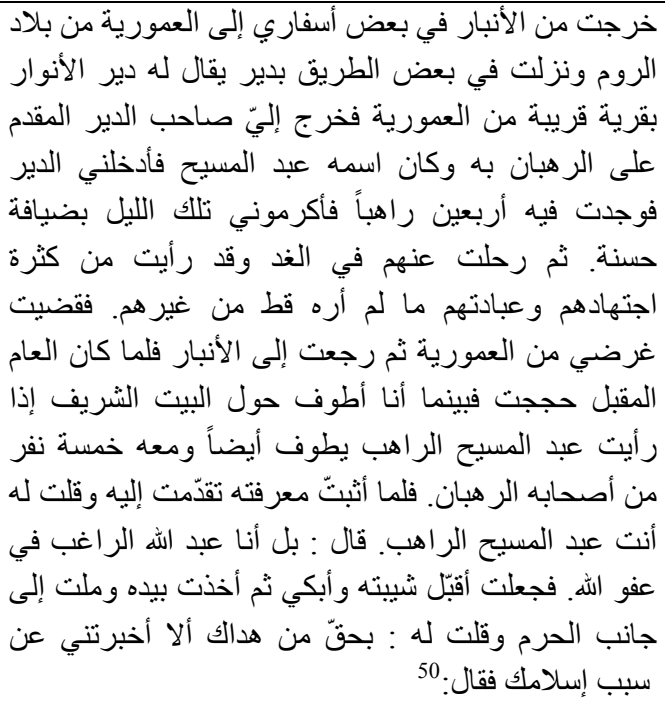 \\
\hline
\end{tabular}

48 "Ammūriya is the Arabic name of the famous stronghold of Amorium in Phrygia, situated on the great Byzantine road from Constantinople to Cilicia: Canard, "Ammūriya," $E I^{2}$, I, p. 449a.

${ }_{49}$ "There was in "Ammūriya a monk called "Abd al-Masih who became Muslim. He was asked the reason for his conversion and said...," Mughultāy, al-Wādih, p. 260.

50 "In one of my travels to "Ammūriya in Byzantine territory, I left al-Anbār and I stopped over in a convent called Dayr al-Anwār in a village near "Ammūriya. The head of the convent, a monk called 'Abd al-Masīh welcomed me and let me in. I found that forty monks lived in the convent. They were very hospitable that night. The following day I left with the realisation that they were very pious and devout. I had never seen the like of it anywhere else before. I fulfilled my task in 'Ammūriya and I came back to 'Anbār. The following year, I went on the pilgrimage and while I was circumambulating the Kaaba, I saw the monk 'Abd al-Masinh who was circumambulating together with five others monks. After confirming his identity, I approached him and said: "You are "Abd al-Masīh the monk". He answered me: "No, I'm "Abd Allāh, he who desires the forgiveness of God." I started kissing his beard and weeping, then I took his hand, after having brought him to the side, I said to him: "In the name of the One who showed you the right way, tell me what made you convert to Islam". He said...," al-Shayzarī, Rawdàt al-qulūb, pp. 128-129. 


\begin{tabular}{|c|c|}
\hline Al-Wādịh & Rawdat al-qulūb \\
\hline 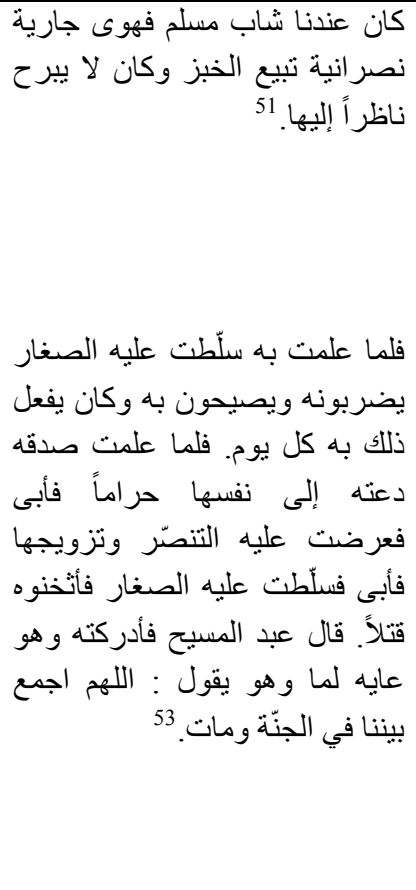 & 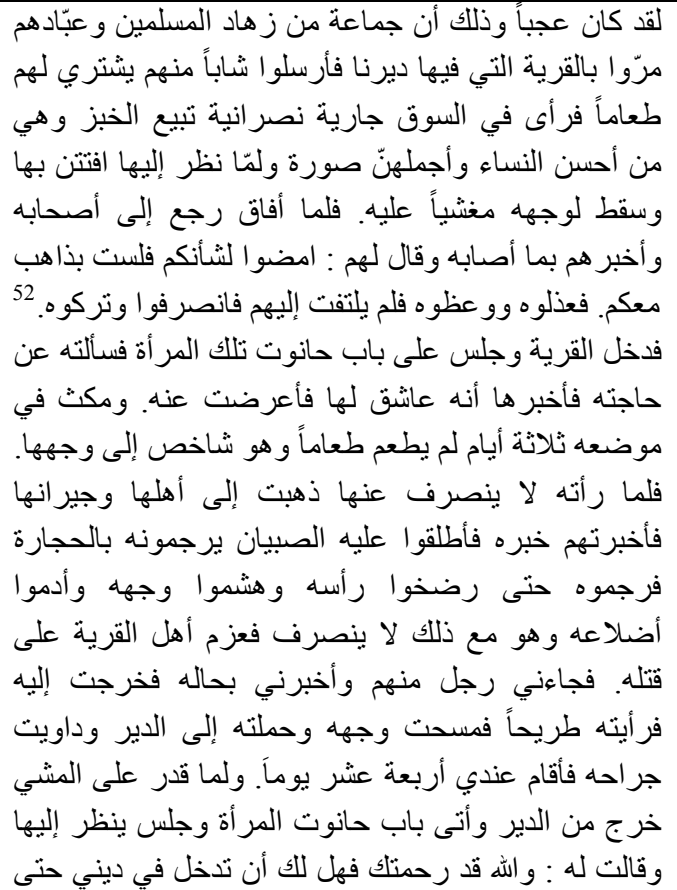 \\
\hline
\end{tabular}

51 "There was in our village a young Muslim man who fell in love with a Christian woman who was selling bread. He couldn't help himself looking at her all the time," Mughulțayy, al-Wādih, pp. 260-261.

52 "It is really amazing. A group of pious Muslims passed by the village where our convent is located, and they sent a young man to buy some food. He saw a Christian woman who was selling bread in the market. She was very beautiful and when he saw her, he became infatuated and fainted. When he came round, he came back to his companions and told them what happened to him. He exhorted them to go away without him as he wanted to stay in the village. They scolded him and warned him, but he did not listen to them. So they left him alone in the village," al-Shayzari, Rawdat al-qulüb, p. 129.

53 "When she discovered the reason of his stay, she made the children hit him and shout at him. Every day was the same. When she was sure of his sincerity, she summoned him and proposed to him that they have an illicit relationship, but he refused. Then she asked him to convert to Christianity in order to marry her, but he refused that too. She told the children to stone him. 'Abd al-Masīh added: I got to him when he was dying and I heard him saying that God will bring them together in Paradise. Then he died," Mughultāy, al-Wädih, p. 261. 


\begin{tabular}{|c|c|}
\hline Al-Wādih & Rawdat al-qulūb \\
\hline & 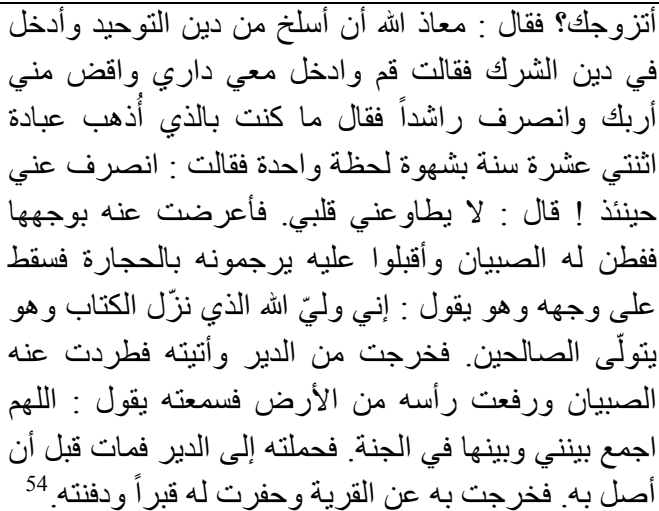 \\
\hline
\end{tabular}

54 "He entered the village and sat at the doorway of this woman's bakery. She asked him what he wanted and he said that he loved her. She turned away from him. He stayed there for three days without eating, just looking at her face. When she saw that he would not go away, she went to her family and to her neighbours and told them about what was happening. They allowed the children to throw stones at him until they hit his head, bruised his face and broke his ribs. Despite this, he did not go away and the people of the village decided to kill him. One of their men came to me to tell me about this. I hurried to him and saw him lying on the ground. I wiped his face and took him to the convent where I treated his wounds. He stayed with me for fifteen days, but, as soon as he was able to stand, he left the convent to go back to the woman's bakery. While he was sitting looking at her, she said to him: "By God, I pity you. Will you convert to Christianity and marry me?" He answered: "God forbids me from abandoning the religion of the one and only God, and to enter a religion which associates with other gods". She then said: "Stand up and come to my house. You will satisfy your lust with me and go away". "I'm not going to waste my devotion of twelve years to experience a pleasure that will last a second," he replied. Then, she ordered him to go away, but he answered that his heart would not allow him to do so. She turned her face from him and called the children. They came and stoned him. He fell on his face, saying: "I am close to God who made the Koran come down and who takes care of the pious." I came out of the convent, and went to him and chased the children away. I lifted his head from the ground and I heard him saying: "God will bring us together in Paradise". I carried him to the convent but he died before we got there. I went out of the village and buried him," al-Shayzarī, Rawdat al-qulüb, pp. 129-130. 


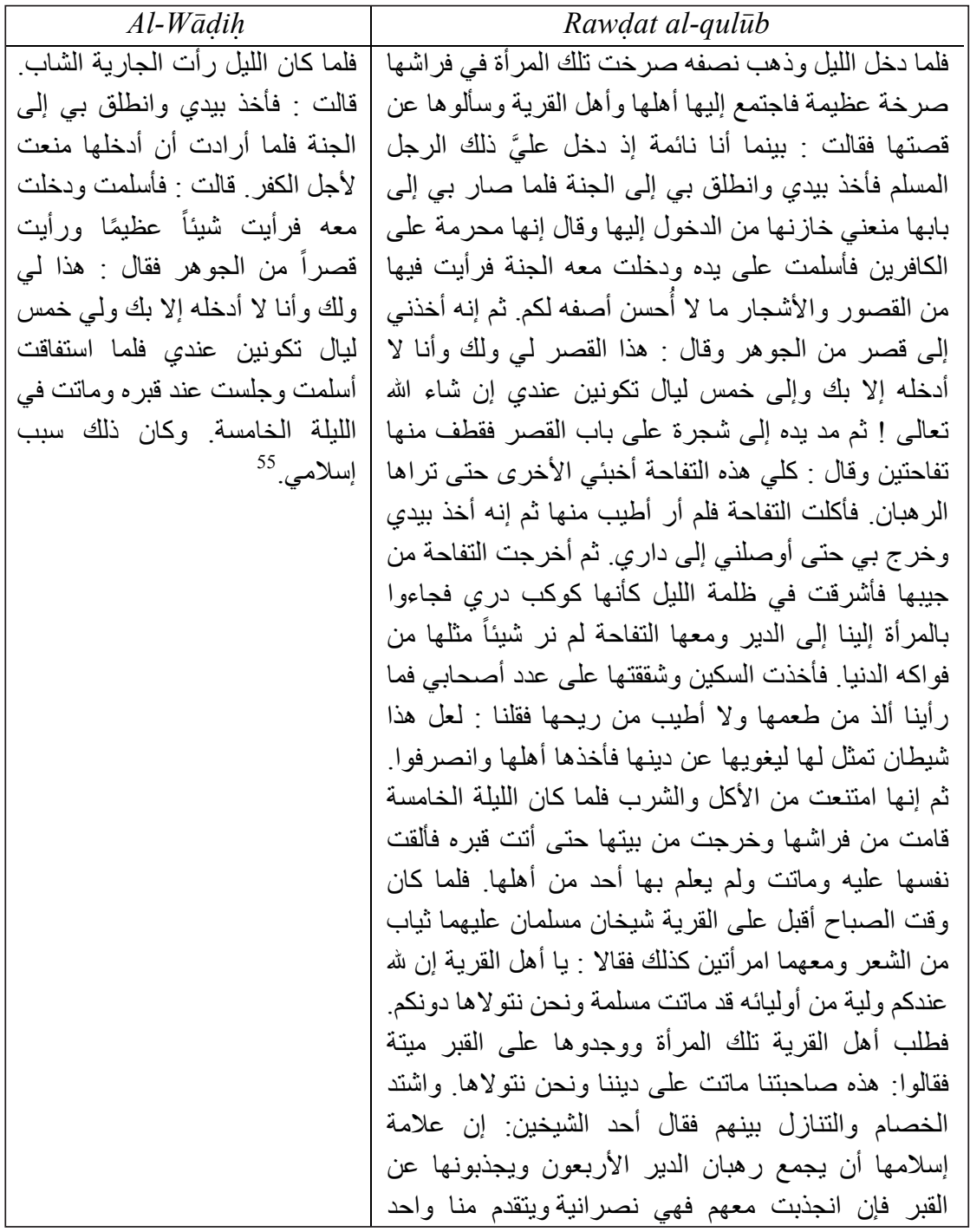

55 "In the night the woman saw the young man in her dreams. She said: "He took my hand and took me to the Paradise. I wanted to enter but I was not allowed to, because of my beliefs. I converted to Islam and I entered with him. I saw great things there. I saw a castle made of jewels and he said: this is for you and me, but I will not enter it without you. You will be with me in five night's time". When she woke up, she converted to Islam and sat by his tomb until she died on the fifth night. This is the reason of my conversion to Islam,” Mughulțāy, al-Wādih p. p. 261. 


\begin{tabular}{|c|c|}
\hline Al-Wādih & Rawdat al-qulūb \\
\hline & 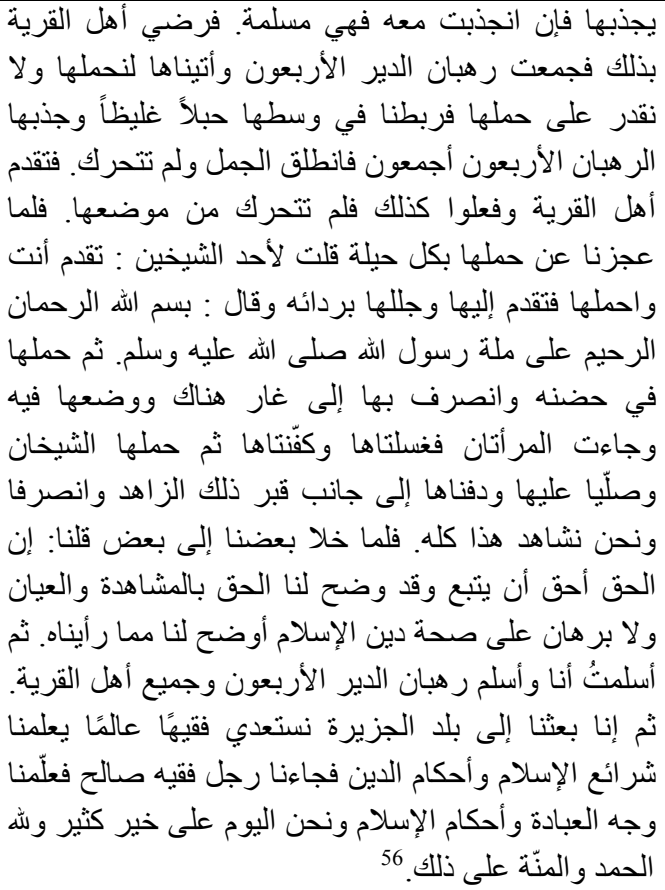 \\
\hline
\end{tabular}

56 "When half the night had passed, that woman screamed very loudly in her bed. Her family and the people of the village gathered around her and asked her why she had screamed. She said: "While I was asleep, that Muslim man entered my room and took my hand. He took me to Paradise but when I went to its doors, the guardian would not let me enter because infidels are not allowed in. I converted to Islam and entered Paradise with him. I saw castles and trees so beautiful that they are beyond description. He took me to a castle made of jewels and told me: "This castle is for you and me, but I will not enter it without you. In five nights time you will be with me, if God Almighty wants it". Then, he raised his hand to a tree that was at the entrance of the castle, took two apples and told me: "Eat one and keep the other to show to the monks". I ate the apple: I have never tasted a more delicious one before. Then he took my hand and brought me back home". She took the apple out of her pocket and it twinkled in the obscurity like a star. They brought the woman to us at the convent. She had the apple with her: amongst all the fruits in the world I have never seen anything like it. I took a knife and cut a piece of it for each of my companions: we had never tasted anything so delicious nor have smelt anything so perfumed, although we thought that Satan had come to her [with the apple] to turn her away from her religion. Her people took her and they went away. She neither ate nor drank until the fifth night when she got out of bed, left her house and went to the [young man's] tomb. She threw herself on it and died without any of her family knowing. The following morning two old Muslim men dressed in fur, in the company of two women, arrived at the village. They said: "People of the village, you have with you a holy woman who has died a Muslim. 
A comparison between these two stories reveals the following omissions made by Mughultāy:

- The story of the rāât's first visit to Anwār's convent and his meeting with the Abbot at Mecca.

- The first attack on the young man and his subsequent treatment at the convent.

- The story of the delicious apple.

- The quarrelling between the people of the village and the Muslims around the body of the young women.

The elements missing from Mughultāy's version of the story are ones which make Shayzarî's khabar an edifying story for the people. Some sequences of the story take place in Mecca, where he met a man that had once been a fervent Christian monk. The evocation of Paradise, the presence in the story of magical objects like the apple and other extraordinary events, like the difficulty experienced by monks in taking the woman's body away show that al-Shayzari's version of the story is meant to surprise and reinforce the faith. All the fantastic elements which in al-Shayzarì's story are there to demonstrate that Islam is superior to Christianity are absent from Mughultāy's version. What interests him is not the edifying quality of the story, but the behaviour of

We will take care of her instead of you". The people of the village searched for the woman and found her dead on the grave. They said: "Our friend died a Christian and we will take care of her". They started discussing this and quarrelling until one of the old men said: "We will have proof that she is Muslim if forty monks try to pull her away from the tomb. If she does go with them, she is Christian. Then one of us will try to pull her and if she does go with him, she is Muslim". The people of the village agreed to this. The forty monks and me gathered and came along to pull her, but we could not. We took a thick rope and tied it to her waist. The forty monks as well as a camel pulled her, but she did not move from the graveside. The people of the village joined us, but again she did not move from where she was. When we realized that there was no means of moving her, I said to one of the sheikhs: "Come along and take her". He did so and enveloped her in his robes saying: "In the name of Allah the Merciful, in the religion of the Prophet of God (the blessings of Allah upon him)". Then he carried her on his chest and brought her to a cave where he laid her down. Two women came to wash her and dress her for the burial. Then the two sheikhs took her, prayed over her body, buried her at the side of that pious man and went away. We witnessed all this and after having been left alone, we said to each other: "The truth is worth following. We had witnessed it directly. There cannot be clearer proof that Islam is the true religion after what we have seen. Then I, the forty monks, and the people of the village, all converted to Islam. We sent a request to Arabia to have a jurist teach us Islamic law and the fundamental tenets of Islam and we got a good jurist who taught us the different aspect of devotion and the fundamental tenets of Islam. We are very happy now thanks to Allah and to His blessing". 
the young Muslim man and how he died as a martyr to love. The khabar is preceded by mention of shahìd and not shahidān indicating that only the suffering and death of the young man interests Mughultāy.

Through these omissions, this author ends up with a completely different tale serving a different purpose. While Shayzarī's tale praises Islam against Christianity, Mughulțāy's pays tribute to the behaviour of the young man and to his martyrdom to love.

\section{Conclusion}

Mughultāy's book occupies a unique position in the history of the love treatise genre. Although he quotes theories on love that predate his book and tells stories that were already part of the literary tradition, through his original approach and by carefully choosing his quotations, he elaborates an original theory of love, and alters earlier traditions in order to support his own arguments. Through his theory of love and his idea of 'ishq, Mughultāy builds a new ethic of love that competes with the ethic of Islam itself. Of all virtues, Mughultāy believes 'ish $q$ is the highest one, and according to Mughultây's ethics, the example to follow in life is that of the passionate lover who eventually dies because of his love.

He similarly alters the earlier love tradition (transforming a fata inclined to love adventures like Waḍāh al-Yaman into a lover of the 'udhri model), introduces new figures of lovers and martyrs to love (like he did with Yazid), and changes the 'pedagogical' value of a story omitting part of its content (i.e. the case of the young Muslim man who died for the love of a Christian girl). The fundamental reason why Mughultāy altered the earlier traditions was to give examples of pious behaviour that must be followed. In this way he builds up the myth of an ideal man (or woman) that is going to replace the homo islamicus described in the sunna. That man (or woman), even if he has been a 'bad caliph' for neglecting his duties to govern the Umma owing to his absolute passion or has committed a major sin by entering the caliph's wife's room in secret or has renounced his ascetic practise for the love of a human, will still enter Paradise upon his death. This indicates that 'ish $q$ has the virtue of erasing all sins, rendering he who dies for this passion a holy and perfect man. 
To some extent, Mughultāy's theory about love creates a religion that has parallels in Islam. The hadith al- 'ishq is comparable to the sha$h \bar{a} d a$, martyrs of love's stories to the sunna. The lover suffering and dying for his passion is indeed presented in al-Wädih as the ideal model to follow in life, and the shuhada ' in al-Wädih can be seen as being in competition with Prophet Muhammad as an ideal example to follow.

Mughultāy's book on love was therefore found to be subversive by the religious authority of the time, as it creates a new ethic and new religious values competing in more than one aspect with Islam. It can be added also, from the historical point of view, that Mamluks presented themselves as defenders of Sunnite orthodoxy. They relied on orthodoxy on local traditional Egyptian 'ulamă', not on Mamluk scholars. Mughultāy being the son of a Mamluk, he was not part of the legitimate religious elite which was "especially eager to deny the Mamluks any credit for achievement in academic or literary pursuits". ${ }^{57}$ Moreover, Mamluks in general did not teach in Cairo's religious school ${ }^{58}$ and we know that Mughulțāy's hadìth teaching in Cairo was challenged by Egyptian native scholars. The hostility towards Mamluk religious scholar like Mughultāy can therefore have also played a role in alWādih's interdiction.

\section{Sources and bibliography}

\section{Sources}

Abū Bakr al-Rāzī, al-Rasā'il al-falsafiyya, P. Kraus (ed.), Universitatis Fouadi I Litterarum Facultatis Publicationum, fasc. XXII, Cairo, 1939.

Abū 1-Faraj al-Iṣfahānī, Kitāb al-Aghān̄̄, Leiden, Brill, 1900.

Dā'ūd al-Anțākī, Tazȳ̄n al-aswāq fì akhbār al- 'ushshāq, M. al-Tūnjīi (ed.), Beirut, 'Ālam al-kutub, 1993.

Ibn Dāwūd al-Iṣfahānī, Kitāb al-Zahra, A.R. Nykl (ed.), Chicago, The University of Chicago Press, 1932.

Ibn Ḥajar al-'Asqalānī, al-Durar al-kāmina fì a 'yān al-mi'a al-thāmina, Hayderabad, Majlis dā'irat al-ma'ārif al-'uthmāniyya al-kā'ina fì l-Hind, $1350 \mathrm{H}$.

Ibn Qayyim al-Jawziyya, Rawdat al-muhibbīn wa-nuzhat al-mushtāqìn, Beirut, Dār al-kutub al-'ilmiyya, 1992.

57 Berkey, The transmission of knowledge in Medieval Cairo, p. 142.

58 Berkey, The transmission of knowledge in Medieval Cairo, pp. 152-153. 
Ibn Quṭlūbughā, Tāj al-tarājim fì tabaqāt al-ḥanafiyya, Bagdad, Maṭba'at al- 'Ānī, 1962.

Ibn Taghrī Birdī, al-Nujūm al-zāhira fì mulūk Miṣr wa-l-Qāhira, Cairo, Wizārat al-thaqāfa wa-l-irshādāt al-qawmiyya, n. d.

al-Jāḥiz, Rasā'il al-Jāḥiz, 'Abd al-Salām Muḥammad Hārūn (ed.), Beirut, Dār alJìl, 1991.

al-Jāḥiz, Risālat al-Nisā', in Majmū 'at rasā'il, Cairo, Maṭba'at al-taqaddum, n. d. al-Khațīb Baghdādī, Ta'rīkh Baghdād, Beirut, Dār al-kutub al-'ilmiyya, n. d.

Mughulțāy, al-Wādih al-mubìn fì dhikr man ustushhida min al-muhibbìn, Beirut, Mu'assasat al-intishār al-'arabī, 2007.

al-Șafadī, A 'yān al- 'aṣr wa-a 'wān al-naṣr, Beirut, Dār ihyā' al-turāth al-'arabī, 2000.

al-Shayzarī, Rawdat al-qulūb wa-nuzhat al-muhibb wa-l-mahbūb, D. Semah and G.J. Kanazi (ed.), Wiesbaden, Harrassowitz Verlag, 2003.

al-Suyūṭị, Dhayl Ṭabaqāt al-Huffạz li-l-Dhahabì, Jerusalem-Damascus, 1333$1334 \mathrm{H}$.

al-Suyūṭ̂̀, al-Durar al-muntathira fì l-ahāìith al-mushtahira, Muhammad 'Abd alQādir 'Ațā' (ed.), Cairo, Dār al-i'tișām, li-l-țab’ wa-l-nashr wa-l-tawzìie, 1987. al-Tawhịīì, al-Baṣā'ir wa-l-dhakhā'ir, Wadād al-Qāḍī (ed.), Beirut, Dār Șādir, 1988.

al-Zamakhsharī, Rabī ‘ al-abrār wa-nuṣūṣ al-akhbār, S. al-Nu'aymī (ed.), Bagdad, Maṭba'at al-'Ānī, 1980.

\section{Bibliography}

Arazi, A., "Waḍḍ̄h al-Yaman," in $E I^{2}$, XI, p. 13.

Arkoun, M., "“Ishk," in $E I^{2}$, IV, p. $118 \mathrm{~b}$.

al-'Aẓm, Ș.J., Fì l-hubb wa-l-hubb al-'udhrī, Damascus, Dār al-Madā li-l-thaqāfa wa-l-nashr, 2002.

Balda-Tillier, M., “Genèse et essor d'un genre littéraire: les traités d'amour dans la littérature arabo-islamique médiévale (II'/VIII - VIII $/$ XIV ${ }^{\mathrm{e}}$ siècle)," Synergies Monde Arabe, 6 (2009), pp. 121-130.

Balda-Tillier, M., Un traité d'amour tardif: les précis des martyrs de l'amour de Mugultāy, PHD thesis, Lyon, Lyon 2 University, 2009.

Bell, J. N., Love Theory in Later Hanbalite Islam, Albany, State University of New York Press, 1979.

Ben Slama, R., al-'Ishq wa-l-kitāba, Cologne, al-Kamel Verlag, 2003.

Berkey, J., The transmission of knowledge in Medieval Cairo. A Social History of Islamic Education, Princeton, Princeton University Press, 1992.

Biesterfeldt, H.H. and Gutas, D., "The malady of Love," Journal of the American Oriental Society, 104 (1984), pp. 21-55. 
Canard, M., " “Ammūriya,” in $E I^{2}$, I, p. 449a.

Gaunt, S., Love and Death in Medieval French and Occitan Courtly Literature Martyrs to Love, Oxford, Oxford University Press, 2006.

Giffen, L.A., Profane Love among the Arabs, the Development of the genre, New York, New York University Press, 1971.

Gruendler, B., "Pardon Those Who Love Passionately," in Friederike Pannewick (ed.), Martyrdom in Literature. Visions of Death and Meaningful Suffering in Europe and the Middle East from Antiquity to Modernity, Wiesbaden, Reichert Verlag, 2004, pp. 200-236.

Jacobi, R., "The "Udhra: Love and Death in the Umayyad Period," in F. Pannewick (ed.), Martyrdom in literature. Visions of Death and Meaningful Suffering in Europe and in the Middle East from Antiquity to Modernity, Wiesbaden, Reichert, 2004, pp. 137-148.

Jarrar, M., "The martyrdom of passionate lovers, Holy war and sacred wedding," in A. Neuwirth, B. Embalo, S. Gunther and M. Jarrar (eds.), Myths, historical Archetypes and symbolic figures in Arabic literature, Beirut, Franz Steiner Verlag, 1999, pp. 87-107.

Jid'ān, F., "Dā'ī al-mushākala fì naẓariyyat al-ḥubb 'inda al-'Arab," in Dirāsāt 'arabiyya wa-sharqiyya, Beirut, al-Jāmi'a al-amrikiyya fì Bayrūt, 1981.

Lammens, H. -[Kh. Y. Blankiship], "Yazīd II, b. 'Abd al-Malik," in $E I^{2}$, XI.

Leder, S., Ibn al-Ǧauzi und seine Kompilation wider die Leidenschaft, Wiesbaden-Beirut, Franz Steiner Verlag, 1984.

Miskinzoda, G., On the margins of sìra: Mughultāa' $\bar{\imath}$ (689-762/1290-1361) and his place in the development of sira literature, PHD thesis, London, SOAS, University of London, 2007.

Pannewick, F., "The Martyred Poet on the Cross in Arabic Poetry," in F. Pannewick (ed.), Martyrdom in Literature Visions of Death and Meaningful Suffering in Europe and in the Middle East from Antiquity to Modernity, Wiesbaden, Reichert, 2004, pp. 105-124.

Rosenthal, F., "Ibn Abī Țāhir al-Tayfür," in $E I^{2}$, III, p. 692 b.

Sicard, F., "L'amour dans la Risālat al-Qiyān - essai sur les esclaves chanteuses - de Ğāhiz (m. 255/868)," Arabica, 34 (1987), pp. 326-338.

Souissi, R., "Waḍḍāh al-Yaman le personnage et sa légende," Arabica, 17 (1970), pp. 252-308.

Recibido: $01 / 08 / 2013$

Aceptado: 08/02/2014 